\title{
THE MODEL OF GREEN BEHAVIOURAL INTENTION AMONG WOMEN ENTREPRENEUR: A QUANTITATIVE STUDY
}

\author{
Asyiffa Fitri Awallia $\left.{ }^{*}\right)$, Melia Famiola ${ }^{*}$ \\ *School of Business and Management, Institut Teknologi Bandung \\ Jl. Ganesa No.10, Lb. Siliwangi, Bandung, Jawa Barat, 40132, Indonesia
}

\begin{abstract}
Today, business activities seem to have shifted towards green business with the inception of women entrepreneurs who are more environmentally conscious. This study aims to examine the behaviour construction of women entrepreneurs' intention towards green business in Indonesia. Using a quantitative approach, data were collected from 122 women entrepreneurs using simple random sampling, which were then processed by PLS-SEM. This study found that green behavioural intention among women entrepreneurs in Indonesia reflects their environmental concern with a strong solid vision to create the change. The argument that market rationality will mediate green business behaviour and predicted as a barrier factor to their intention of having business with environmental concerns was not proven. This study argues that women entrepreneurs with green business initiatives in Indonesia belong to the visionary champion type, an entrepreneur who takes themselves as agents of change. Increasing the number of women entrepreneurs with green business initiation in Indonesia will favour Indonesia's future economy and sustainability. The nurture of women's role in spreading knowledge allows them to create their market by educating the market with their green image and offering alternatives. The government needs to pay strict attention and formulate policies on encouraging women entrepreneurs in Indonesia, particularly those starting their business with environmental consciousness.
\end{abstract}

Keywords: women entrepreneurs, green business, behavioural intention, sustainable development goals, Indonesia

\begin{abstract}
Abstrak: Aktivitas bisnis saat ini telah bergeser ke arah bisnis hijau dengan lahirnya wirausaha perempuan yang lebih sadar lingkungan. Penelitian ini bertujuan untuk mengkaji konstruksi niat perilaku perempuan pengusaha terhadap green business di Indonesia. Dengan menggunakan pendekatan kuantitatif, data dikumpulkan dari 122 perempuan pengusaha menggunakan simple random sampling, yang kemudian diolah dengan metode PLS-SEM. Studi ini menemukan bahwa niat perilaku hijau di kalangan perempuan pengusaha di Indonesia mencerminkan kepedulian mereka terhadap lingkungan dengan visi yang kuat untuk menciptakan perubahan. Argumen rasionalitas pasar akan memediasi perilaku bisnis hijau dan diprediksi sebagai faktor penghambat niat untuk berbisnis hijau tidak terbukti. Studi ini berpendapat bahwa wirausaha perempuan dengan inisiatif bisnis hijau di Indonesia termasuk dalam tipe juara visioner, yaitu wirausaha yang menjadikan dirinya sebagai agen perubahan. Meningkatkan jumlah wirausaha perempuan dengan inisiasi bisnis hijau akan mendukung perekonomian dan keberlanjutan masa depan Indonesia. Peran perempuan dalam menyebarkan pengetahuan memungkinkan mereka menciptakan pasar dengan mendidik pasar dengan citra hijau dan menawarkan alternatif. Pemerintah perlu mencermati dan merumuskan kebijakan yang mendorong perempuan pengusaha di Indonesia, khususnya yang memulai usahanya dengan berwawasan lingkungan.
\end{abstract}

Kata kunci: perempuan pengusaha, bisnis hijau, niat perilaku, sustainable development goals, Indonesia.

${ }^{1}$ Corresponding author:

Email: asyiffa-fitri@sbm-itb.ac.id 


\section{INTRODUCTION}

Environmental issues have been declared as a crucial problem faced by all countries. It becomes more complicated from the time being because of extreme climate change and other environmental destruction. The Intergovernmental Panel on Climate Change (IPCC) mentioned that human activities are crucial in accelerating climate change, mainly fossil fuel burning for transportation and industry (IPCC, 2013). It is predicted that environmental issues generate other environmental risks such as biodiversity loss, food scarcity, health, and socio-economic problems. For this reason, The United Nations (2015) has established seventeen Sustainable Development Goals (SGDs) as an effort to persuade humankind to protect the planet and improve the quality of life, including in production and consumption activities (SDG 12). Thus, today's business activities need to shift from focusing solely on financial gain to emphasizing the triple bottom line; economic, environmental, and social (Alwakid et al. 2020; Gast et al. 2017; Haldar, 2019).

Even though there is pressure to achieve the SDGs, there has not been much shift towards an environmentally conscious business or green business in Indonesia. According to data from the Ministry of Agriculture, there are only 33 companies that have received green certificates and are dominated by medium and large companies (Kementerian Perindustrian, 2020). Despite limited data regarding green business in Indonesia, we find many new companies and traditional businesses starting to reveal their awareness of environmentally friendly practices, especially from the SME sector (Famiola \& Wulansari, 2019; Raharjo, 2019).

Previous research has explored the factors that influence owners to engage in environmentally friendly practices and how they have translated those factors into green business behavior (Ashton et al. 2017; Gast et al. 2017; Jiang et al. 2020; Soomro et al. 2020). However, none of them focuses on the role of women. In contrast, according to Ahmad (2019) and Braun (2010), women entrepreneurs are relatively engaged with green business because they care about the environment rather than their counterparts. They have a green cooperative to generate income, engage more employees, and provide impact. In Indonesia, the number of women entrepreneurs increases recently.
They could be the potential driver of Indonesian economic growth. According to The Asia Foundation (2013), 57\% of Indonesian Gross Domestic Product is funded by small businesses, and women produce $23 \%$.

This study addresses how women contribute to achieving the SDGs, particularly for women who run a business. We argue the nurture of women's role as a mother and caretaker could actively reduce poverty by spreading knowledge to other women through various initiatives (Harris et al. 2020; Hlahla et al. 2016; UN, 2012). Furthermore, we believe that exploring women entrepreneurs' behavior in Indonesia as agents of change towards a green business is necessary by understanding their intention to create a business and become green businesswomen.

\section{METHODS}

A deductive approach using quantitative methods was conducted in this study. After one month of data collection in November 2020, we collected 122 respondents from different regions and industries to represent women entrepreneurs in Indonesia using simple random sampling. The number of respondents in this study followed the rule of thumb, which was ten times the most significant number of formative indicators used to measure a single construction (Hair et al. 2017).

The cross-sectional design to construct the questionnaire was employed, and the questionnaire was completed through an online survey. To facilitate communication, we used appropriate Indonesian and apply a fivepoint Likert scale ranging from strongly disagree (1) to strongly agree (5) with a total of 24 indicators as questions. This study's questionnaire is divided into two sections: the socio-demographic profile and the research statement regarding the six constructs, namely: environmental awareness, entrepreneurial capacity, green business intention, market rationality, support factors, and green business behavior. The measurement of the six constructs is based on previous research that we adopted and modified according to the context of this study (A measurement property of constructs portrayed in Table 1). These constructs result from a literature review created for the research framework (Figure 1). 
Table 1. A measurement property of constructs

\begin{tabular}{|c|c|c|}
\hline Constructs & Item & Measurement \\
\hline \multirow{5}{*}{$\begin{array}{l}\text { Environmental } \\
\text { Awareness (EA) } \\
\text { (Ellen, 1994; } \\
\text { Lillemo, 2014) }\end{array}$} & EA1 & I feel that environmental issues are important \\
\hline & EA2 & I think environmental protection is needed \\
\hline & EA3 & I feel I have a responsibility to protect the environment \\
\hline & EA4 & $\begin{array}{l}\text { To protect the environment, I feel the need to reduce energy consumption (e.g., minimizing } \\
\text { electricity or fuel oil) }\end{array}$ \\
\hline & EA5 & I feel everyone should participate in environmental protection activities \\
\hline \multirow{4}{*}{$\begin{array}{l}\text { Entrepreneurial } \\
\text { Capacity (EC) } \\
\text { (Anggadwita \& } \\
\text { Dhewanto, 2016; } \\
\text { Raharjo, 2019) }\end{array}$} & $\mathrm{EC} 1$ & I can see opportunities to run a business \\
\hline & $\mathrm{EC} 2$ & I have the knowledge and skills to develop a business idea \\
\hline & EC3 & I can communicate and network with other people \\
\hline & EC4 & I get support and convenience in running my business \\
\hline \multirow{6}{*}{$\begin{array}{l}\text { Green Business } \\
\text { Intention (GBI) } \\
\text { (Chen \& Liñán, } \\
\text { 2008) }\end{array}$} & GBI1 & I am ready to do anything to implement environmentally friendly business activities \\
\hline & GBI2 & I aspire to implement environmentally friendly business activities in my company \\
\hline & GBI3 & I will try my best to start and run an environmentally friendly business \\
\hline & GBI4 & $\begin{array}{l}\text { I am determined to create an environmentally friendly business in the future to help reduce } \\
\text { environmental problems }\end{array}$ \\
\hline & GBI5 & I am seriously thinking about starting an environmentally friendly business \\
\hline & GBI6 & I have a solid intention to start an environmentally friendly business in the future \\
\hline \multirow{3}{*}{$\begin{array}{l}\text { Market Rationality } \\
\text { (MR) } \\
\text { (Bendell, 2017) }\end{array}$} & MR1 & Consumers have not considered the environmental impact of a product \\
\hline & MR2 & Consumers do not have awareness about environmentally friendly products \\
\hline & MR3 & There is no demand from consumers to produce environmentally friendly products \\
\hline \multirow{2}{*}{$\begin{array}{l}\text { Support Factors } \\
\text { (SF) } \\
\text { (Chen \& Liñán, } \\
\text { 2008) }\end{array}$} & SF1 & My family supports me to do environmentally friendly business activities \\
\hline & SF2 & My family help me to do environmentally friendly business activities \\
\hline \multirow{4}{*}{$\begin{array}{l}\text { Green Business } \\
\text { Behaviour (GBB) } \\
\text { (Hosseininia \& } \\
\text { Ramezani, 2016; } \\
\text { Paulraj et al. 2017) }\end{array}$} & GBB1 & In the production process, the company uses environmentally friendly materials or recycles \\
\hline & GBB2 & $\begin{array}{l}\text { In the production process, the company does not have garbage or has a proper waste dis- } \\
\text { posal system }\end{array}$ \\
\hline & GBB3 & The packaging used by the company uses the most friendly materials or reuses \\
\hline & GBB4 & Companies carry out evaluations to reduce environmental impacts \\
\hline
\end{tabular}

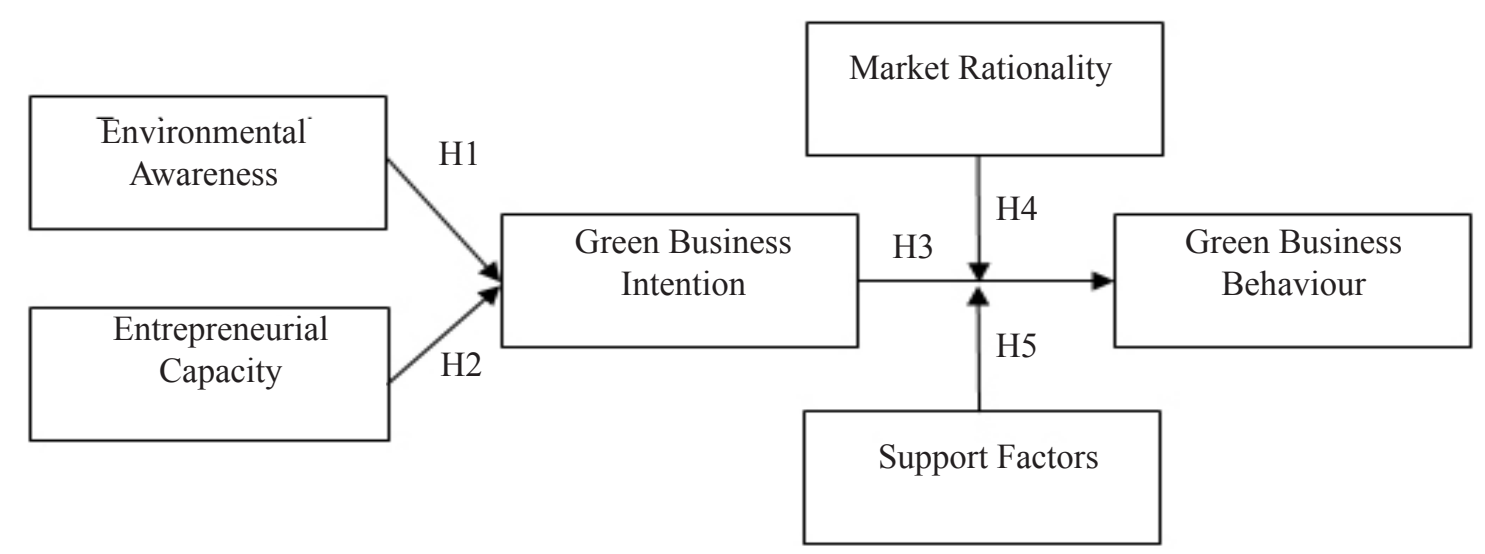

Figure 1. Conceptual framework of green behavioural intention among women entrepreneurs in Indonesia 
We used PLS-SEM to analyze data since it was the appropriate method for the theory development stage. Also, PLS-SEM can examine the correlation between constructs (interrelated dependence) and between constructs and their measures based on variance. In this study, a two-step measurement model was used with smart PLS 3. First, a measurement model with reliability and validity among indicators and constructs. Second, the structural measurement model evaluates the model fit and hypothesis test (Hair et al. 2017).

H1: Environmental awareness has a positive influence on green business intention among women entrepreneurs in Indonesia.

$\mathrm{H} 2$ : Entrepreneurial capacity has a positive influence on green business intention among women entrepreneurs in Indonesia.

H3: Green business intention has a positive influence on green business behavior among women entrepreneurs in Indonesia.

H4: Market rationality mediated women entrepreneurs' green business intention on green business behavior in Indonesia.

H5: Support factor-mediated women entrepreneurs' green business intention on green business behavior in Indonesia.

\section{RESULT}

\section{Respondent Characteristics}

The majority of the respondents of this study are aged $17-25$ years $(71 \%)$, indicating that they are still young and at a productive age. Most of them are single (64.5\%) and have a bachelor's degree $(65.3 \%)$, meaning that they are educated and have no responsibility towards the family. The average business they own has been operating for three months -3.5 years. It is included in the total early-stage of entrepreneurial activity, namely the owner-manager of a new business. Furthermore, most of them are engaged in fashion (33.9\%) and food $\&$ beverage $(32.3 \%)$, indicating that they are trying to meet primary human needs.

\section{Measurement Model Fit}

The analysis began with the assessment of the reflective model. A reliability test was used to see the intercorrelation of the observed indicators. Based on Table 2, the value of Cronbach Alpha and Composite Reliability surpasses the boundary of 0.7 (Hair et al. 2014), internal consistency reliability was met. Avalidity test with convergent validity was used to determine the suitability of indicators positively correlated with alternative sizes of a construct by considering the loading factor and AVE. Discriminant validity was used to see the differences between constructs, considering the Fornell-Larcker criterion. The loading factor value is greater than the threshold value of 0.708 , and the AVE value is higher than 0.5 (Hair et al. 2017), convergent validity is met. Likewise, discriminant validity with the Fornell-Larcker (as shown in Table 3) fulfilled the requirements. Square roots of the AVEs surpass all the construct's correlation; thus, discriminant validity is met.

The second stage is the formative model's measurement with the Variance Inflation Factor (VIF) values ranging from 1.510 - 4.991, lower than the maximum value of 5 (Hair et al. 2014); thus, there were no multicollinearity issues among the predictor constructs. Therefore, the measurement of the reflective model and the measurement of the formative model is met.

\section{Evaluation of the Structural Model}

To test the hypothesis, PLS - Structural Equation Modelling was used with 5000 re-samples at a 95\% confidence interval for the bootstrapping technique. The result was reported in Table 4 .

We discovered that Hypothesis 1 is accepted: environmental awareness has a significantly positive influence on green business intention (beta $=0.581$, $\mathrm{t}$-value $>1.96, \mathrm{p}$-value $<0.05)$. This finding is aligned with the previous study in many regions and industries that business owners' environmental awareness affects green business intention (Jiang et al. 2020; Middermann et al. 2020; Raharjo, 2019; Sardianou et al. 2016; Soomro et al. 2020). The primary fundamental factor in developing a green business and what makes it different from the conventional business is the owner's value green trait as substantial. Consistent with the literature, we found that when women entrepreneurs are aware of the environment, they will have confidence in including environmental aspects in business activities and intend towards a green business. 
Table 2. Result of reliability and convergent validity

\begin{tabular}{|c|c|c|c|c|c|}
\hline Construct & Indicators & Cronbach Alpha & Composite Reliability & Loading Factor & AVE \\
\hline \multirow[t]{5}{*}{ EA } & EA1 & 0.832 & 0.88 & 0.722 & 0.596 \\
\hline & EA2 & & & 0.779 & \\
\hline & EA3 & & & 0.802 & \\
\hline & EA4 & & & 0.749 & \\
\hline & EA5 & & & 0.806 & \\
\hline \multirow[t]{4}{*}{ EC } & $\mathrm{EC} 1$ & 0.836 & 0.889 & 0.864 & 0.669 \\
\hline & $\mathrm{EC} 2$ & & & 0.862 & \\
\hline & EC3 & & & 0.793 & \\
\hline & EC4 & & & 0.747 & \\
\hline \multirow[t]{6}{*}{ GBI } & GBI1 & 0.93 & 0.945 & 0.816 & 0.741 \\
\hline & GBI2 & & & 0.807 & \\
\hline & GBI3 & & & 0.915 & \\
\hline & GBI4 & & & 0.852 & \\
\hline & GBI5 & & & 0.885 & \\
\hline & GBI6 & & & 0.885 & \\
\hline \multirow[t]{3}{*}{ MR } & MR1 & 0.81 & 0.887 & 0.819 & 0.724 \\
\hline & MR2 & & & 0.939 & \\
\hline & MR3 & & & 0.788 & \\
\hline \multirow[t]{2}{*}{ SF } & $\mathrm{SF} 1$ & 0.891 & 0.948 & 0.954 & 0.902 \\
\hline & SF2 & & & 0.945 & \\
\hline \multirow[t]{4}{*}{ GBB } & GBB1 & 0.805 & 0.871 & 0.752 & 0.628 \\
\hline & GBB2 & & & 0.749 & \\
\hline & GBB3 & & & 0.815 & \\
\hline & GBB4 & & & 0.85 & \\
\hline
\end{tabular}

Table 3. Result of discriminant validity with the Fornell-Larcker

\begin{tabular}{lcccccc}
\hline & EA & EC & GBB & GBI & MR & SF \\
\hline EA & 0.772 & & & & & \\
EC & 0.427 & 0.818 & & & & \\
GBB & 0.362 & 0.323 & 0.793 & & & \\
GBI & 0.625 & 0.352 & 0.561 & 0.861 & & \\
MR & 0.211 & 0.065 & -0.13 & -0.092 & 0.851 & \\
SF & 0.503 & 0.278 & 0.56 & 0.63 & -0.003 & 0.949 \\
\hline
\end{tabular}

Table 4. Result of hypothesis testing

\begin{tabular}{llcccc}
\hline $\mathrm{H}$ & \multicolumn{1}{c}{ Description } & Beta & t-value & $\mathrm{p}$-value & Result \\
\hline $\mathrm{H} 1$ & Environmental Awareness $\rightarrow$ Green Business Intention & 0.581 & 7.326 & 0 & Supported \\
$\mathrm{H} 2$ & Entrepreneurial Capacity $\rightarrow$ Green Business Intention & 0.104 & 1.055 & 0.146 & Unsupported \\
$\mathrm{H} 3$ & Green Business Intention $\rightarrow$ Green Business Behaviour & 0.331 & 3.37 & 0 & Supported \\
\hline
\end{tabular}

However, Hypothesis 2 is not supported, which means entrepreneurial capacity is not a significant influence for green business intention (beta $=0.104$, t-value $<1.96$, p-value $>0.05$ ). The result is different from the previous study but consistent with Mohammed, Fethi, \& Djaoued(2017), who stated that entrepreneurial capacity does not positively influence green business intention.
We argue that this may happen because the perceived entrepreneurial capacity depends on the context. Ajzen (1991) stated that the perceived behavioral control varies in the context. We associate the entrepreneurial capacity as women entrepreneurs' behavioral control to the extent they perceive maximizing individual benefits through economic activities. According to this 
study result, we could conclude that the green business belongs to women entrepreneurs in Indonesia who do not put the economic performance as their behavioral control to their intention to develop green business. Further, Taylor \& Walley (2004) explained that a green business that does not pay attention to profit (less profit-oriented) aims to change the industry to make it more sustainable, called green-green business. It can be concluded that women entrepreneurs in Indonesia with a green business intention are not influenced by the desire to gain profits; they tend to be motivated by other pressures and concern how to create the change within the industry to support sustainability as a real practice.

Next, the effect of green business intention on green business behavior has a significant positive influence (beta $=0.331$, t-value $>1.96$, p-value $<0.05$ ), thus: Hypothesis 3 is supported. Consistent with Yi (2020), we discovered that women entrepreneurs in Indonesia carry out green business practices because of prior intention; how they behave is influenced by belief. Thus, when an owner has faith and willingness to participate in green business practices, it will influence green business behavior in the future.

We used specific indirect effects to analyze mediating effects since there is more than one mediator. Based on Table 5, we find that Hypothesis 4 is rejected. Market rationality does not mediate the relationship between green business intention and green business behavior among women entrepreneurs in Indonesia (beta = 0.009 , p-values $>0.05$ ). It means women entrepreneurs in Indonesia who have green business intentions do not consider whether the market will like or need their products or not. Consistent with Spence, Ben Boubaker Gherib, \& Biwolé (2011) stated that green entrepreneurs tend to be pioneers. Although there is no market pressure, green firms are consistent with their practices. Even aligning with the market is challenging to do. They are intended to develop their market. The study proves that people who run pro-environmental behavior tend to be niche companies since the market has not yet been developed.

While Hypothesis 5, support factors, partially mediate the correlation between green business intention and green business behavior (beta $=0.221$, p-value $<0.05)$. When women entrepreneurs have a green business intention and get encouragement from their families, the possibility of shifting or generating a green business will be higher. The result is in line with Baluku et al. (2020), that family support has a vital role in implementing green business intention to green business behavior. Parents and family roles are crucial because they can be sources of funding and are ready to listen (Ahmad, 2019; Setiawati \& Kartini, 2018; Tambunan, 2019). So does green business (Gibbs \& O’Neill, 2017; Potluri \& Phani, 2020). In addition, the majority of respondents are young adults who run micro-businesses. The family's role will help carry out business activities both socially and morally.

\section{Effect Size, Coefficient of Determination, and Predictive Relevance}

Evaluation of the effect size $\left(\mathrm{F}^{2}\right)$ is significant when estimating the structural model (Cohen, 2013). Based on Table 6, environmental awareness has a moderate effect value on green business intention. In contrast, entrepreneurial capacity towards green business intention does not affect it because the value is less than 0.20. However, the green business intention has a moderate effect on explaining green business behavior.

Table 5. Result of mediating effects

\begin{tabular}{llcccc}
\hline $\mathrm{H}$ & Description & Beta & p-value & Result \\
\hline $\mathrm{H} 4$ & Green Business Intention $\rightarrow$ Market Rationality $\rightarrow$ Green Business Behaviour & 0.009 & 0.276 & Unsupported \\
$\mathrm{H} 5$ & Green Business Intention $\rightarrow$ Support Factors $\rightarrow$ Green Business Behaviour & 0.221 & 0.001 & Supported \\
\hline
\end{tabular}

Table 6. Result of effect size

\begin{tabular}{llcc}
\hline $\mathrm{H}$ & \multicolumn{1}{c}{ Description } & Effect size & Result \\
\hline $\mathrm{H} 1$ & Environmental Awareness $\rightarrow$ Green Business Intention & 0.581 & Moderate \\
H2 & Entrepreneurial Capacity $\rightarrow$ Green Business Intention & 0.104 & No effect \\
H3 & Green Business Intention $\rightarrow$ Green Business Behaviour & 0.561 & Moderate \\
\hline
\end{tabular}


Furthermore, we examined the coefficient of determination $\left(\mathrm{R}^{2}\right)$ to examine our model's explanatory power. The $\mathrm{R}^{2}$ values for green business intention, green business behavior, market rationality, and support factors were $0.395,0.4,0.008$, and 0.396 , respectively. Thus, our proposed model explains 39.5\% variance in green business intention, $40 \%$ variance in green business behavior, $0.8 \%$ variance in market rationality, and $39.6 \%$ in support factors.

To find out the capabilities and predictive model, we used Stone Geyser's $\left(\mathrm{Q}^{2}\right)$. The values of $\mathrm{Q}^{2}$ for Environmental Awareness, Entrepreneurial Capacity, Green Business Intention, Green Business Behaviour, Market Rationality, and Support Factors ranging from $0.382-0.63$, more significant than zero. It shows that the path models' predictive relevance. We conclude our model after the test of this study is shown in Figure 2.

\section{Managerial Implications}

Green behavioral intention among women entrepreneurs in Indonesia is driven by their environmental concern with a solid vision to create the change. Their strong commitment is due to their consciousness that today's economy treads to human civilization sustainability. Therefore, innovations to support creating a green business initiative are crucial, and their environmental knowledge. In addition, their green behavior does not put the market demand as their motivation. Based on a previous study, most businesses concerned with green initiatives could create cost efficiency and revenue growth but in a long-time, because most of them have work with product differentiation and hold the ethical standard of transparency. The nurture of women's role in spreading knowledge allows them to create their market by educating the market with their green image and offer alternatives. They are not distracted by the absence of market demand. Furthermore, women's talents as a caretaker could make them easy to be motivated to be involved as problem solvers in the communities and business practices. They could be encouraged to be the agents of change to support sustainability and being a leader to introduce a sustainable behavior.

Increasing the number of women entrepreneurs with green business initiation in Indonesia will favour Indonesia's future economy and sustainability, such as reducing the unemployment rate, and many social and environmental initiatives come from the grass-root initiatives. Many social and environmental initiatives come from grassroots initiatives. Accordingly, we suggest that the government pays strict attention and formulate policies on encouraging women entrepreneurs in Indonesia, particularly those starting their business with environmental consciousness. The support could be an aspect related to financial aids and the wide range of access to the market by giving priority in business permission and getting the green certificate.

\section{CONCLUSIONS AND RECOMMENDATIONS}

\section{Conclusions}

The green business may be a relatively new topic, but currently, there is increasing interest in sustainable development goals and the triple bottom line implementation. This study focuses on women's entrepreneurship in emerging markets, particularly in Indonesia, in green business activities because studies on this topic are still limited.

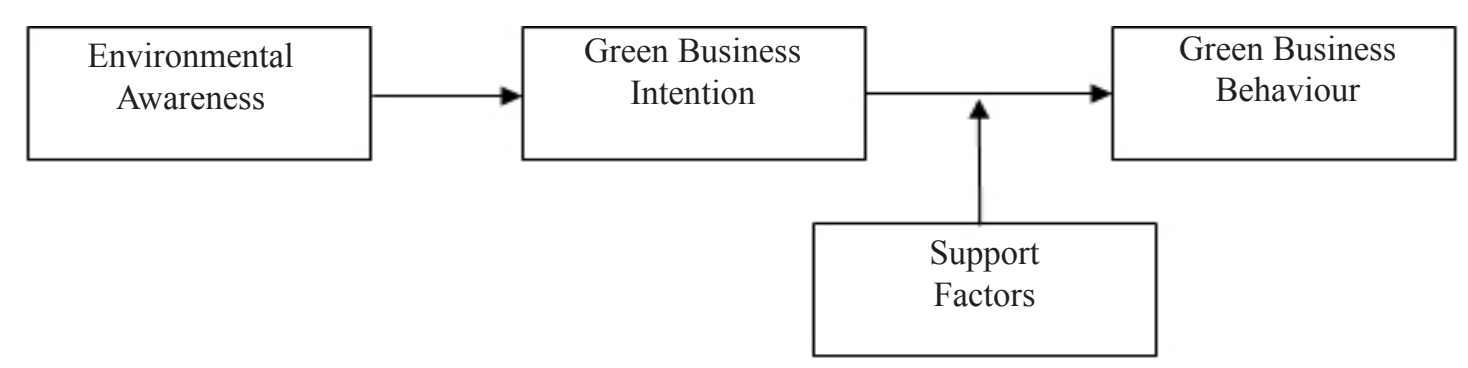

Figure 2. The model of green behavioural intention among women entrepreneurs in Indonesia 
A high level of environmental awareness influences the intention of women entrepreneurs in Indonesia to create businesses and become green entrepreneurs that conventional entrepreneurs do not have. Meanwhile, to translate their intention into green business behavior, support from family is needed, but they do not put market demand as motivation. Accordingly, we argue that the involvement of women entrepreneurs in Indonesia in the green business belongs to the visionary champion type. The type of entrepreneur who puts environmental sustainability as the priority, profits will follow and can be developed through educating the market (Taylor \& Walley, 2004).

Women who are more aware of the environment and their talents as caretakers make it easier to be motivated in green business practices. Moreover, it can be encouraged as agents of change to support the achievement of the SDGs. Therefore support from external parties is very much needed, especially the government.

\section{Recommendations}

Some limitations have been identified in this study. These limitations may serve as a foundation for future research. First, due to the limited time of the study, the number of respondents in our research has not represented all the intentions of women entrepreneurs in Indonesia to shift toward green business. Second, we believe other factors we could elaborate more detail related to women entrepreneurs' green behavior. Our surprising finding related to the missing support factors of entrepreneurial capacity towards women's intention of green business may need more explorative study. Do other variables mediate or moderate to entrepreneurial capacity to green business initiation. Logically, no one intends to develop a business when they do not see the opportunities, even when the opportunity is small.

\section{REFERENCES}

Ahmad A. 2019. Eco-friendly women entrepreneurship in rural areas:a paradigm shift for societal uplift. Jaipuria International Journal of Management Research 5(2):41. https://doi.org/10.22552/ jijmr/2019/v5/i2/189060

Ajzen I. 1991. The theory of planned behavior. Handbook of Theories of Social Psychology 1:438-459. https://doi.org/10.4135/9781446249215.n22

Alwakid W, Aparicio S, Urbano D. 2020. Cultural antecedents of green entrepreneurship in Saudi Arabia:An institutional approach. Sustainability 12(9):1-20. https://doi.org/10.3390/su12093673

Anggadwita G, Dhewanto W. 2016. The influence of personal attitude and social perception on women entrepreneurial intentions in micro and small enterprises in Indonesia. International Journal of Entrepreneurship and Small Business 27(2-3):131-148. https://doi.org/10.1504/ IJESB.2016.073974

Ashton W, Russell S, Futch E. 2017. The adoption of green business practices among small US Midwestern manufacturing enterprises. Journal of Environmental Planning and Management 60(12):2133-2149. https://doi.org/10.1080/096 40568.2017.1281107

Baluku MM, Kikooma JF, Otto K, König CJ. 2020. Positive Psychological Attributes and Entrepreneurial Intention and Action:The Moderating Role of Perceived Family Support 11(December). https://doi.org/10.3389/ fpsyg.2020.546745

Bendell BL. 2017. I don't want to be green:prosocial motivation effects on firm environmental innovation rejection decisions. Journal of Business Ethics 143(2):277-288. https://doi. org/10.1007/s10551-015-2588-2

Braun P. 2010. Going green:women entrepreneurs and the environment. International Journal of Gender and Entrepreneurship, 2(3):245-259.

Chen YW, Liñán F. 2008. Development and crosscultural application of a specific instrument to measure entrepreneurial intentions. Entrepreneurship Theory and Practice:SAGE Journals 852:10.

Cohen J. 2013. Statistical Power Analysis for the Behavioral Sciences. Taylor \& Francis. https:// books.google.co.id/books?id=cIJH01R33bgC

Ellen PS. 1994. Do we know what we need to know? Objective and subjective knowledge effects on pro-ecological behaviors. Journal of Business Research 30(1):43-52. https://doi. org/10.1016/0148-2963(94)90067-1

Famiola M, Wulansari A. 2019. SMEs' social and environmental initiatives in Indonesia:an institutional and resource-based analysis. Social Responsibility Journal 16(1):15-27. https://doi. org/10.1108/SRJ-05-2017-0095

Gast J, Gundolf K, Cesinger B. 2017. Doing business 
in a green way:A systematic review of the ecological sustainability entrepreneurship literature and future research directions. Journal of Cleaner Production 147:44-56. https://doi. org/10.1016/j.jclepro.2017.01.065

Gibbs D, O’Neill K. 2017. Future green economies and regional development:a research agenda. Regional Studies 51(1):161-173. https://doi.org /10.1080/00343404.2016.1255719

Hair JF, Hult GTM, Ringle CM, Sarstedt M. 2017. A Primer on Partial Least Squares Structural Equation Modeling (PLS-SEM). UK:Sage.

Hair JH, Black WC, Babin BJ, Anderson RE. 2014. Multivariate Data Analysis (Seventh). UK:Pearson Education Limited.

Haldar S. 2019. Green entrepreneurship in the renewable energy sector - a case study of Gujarat. Journal of Science and Technology Policy Management 10(1):234-250. https://doi.org/10.1108/JSTPM12-2017-0070

Harris N, Sebar B, Whitehead D, Hatam N, Coyne E. 2020. Women 's Studies International Forum Young Iranian women as agents of social change:A qualitative study - Asiyeh Salehi. January.

Hlahla S, Goebel A, Hill TR. 2016. Green Economy :A Strategy to Alleviate Urban Poverty and Safeguard the Environment? KwaZulu-Natal, South Africa. 113-127. https://doi.org/10.1007/ s12132-015-9263-7

Hosseininia G, Ramezani A. 2016. Factors influencing sustainable entrepreneurship in small and medium-sized enterprises in Iran:A case study of food industry. Sustainability 8(10). https://doi. org $/ 10.3390 / \mathrm{su} 8101010$

IPCC. 2013. Climate change 2013:the physical science basis. contribution of working group i to the fifth assessment report of the intergovern- mental panel on climate change. Cambridge University Press, 1-1535. https://doi.org/10.1017/ CBO9781107415324

Jiang H, Wang S, Wang L, Li G. 2020. Golden apples or green apples? The effect of entrepreneurial creativity on green entrepreneurship:A dual pathway model. Sustainability 12(15). https:// doi.org/10.3390/SU12156285

Kementerian Perindustrian. 2020. RENCANA STRATEGIS Kementerian Perindustrian Tahun 2020-2024. Jakarta:Kemenperin.

Lillemo SC. 2014. Measuring the effect of procrastination and environmental awareness on households' energy-saving behaviours:An empirical approach. Energy Policy 66:249-256. https://doi.org/10.1016/j.enpol.2013.10.077

MiddermannLH, KratzerJ, PernerS. 2020. Theimpact of environmental risk exposure on the determinants of sustainable entrepreneurship. Sustainability 12(4):1-15. https://doi.org/10.3390/su12041534

Mohammed BS, Fethi A, \& Djaoued OB. 2017. The Influence of attitude, subjective norms and perceived behavior control on entrepreneurial intentions:case of algerian students. American Journal of Economics 2017(6):274-282. https:// doi.org/10.5923/j.economics.20170706.02

Paulraj A, Chen IJ, Blome C. 2017. Motives and performance outcomes of sustainable supply chain management practices:a multi-theoretical perspective. Journal of Business Ethics 145(2):239-258. https://doi.org/10.1007/ s10551-015-2857-0

Potluri S, Phani BV. 2020. Incentivizing green entrepreneurship:A proposed policy prescription (a study of entrepreneurial insights from an emerging economy perspective). Journal of Cleaner Production 259:120843. https://doi. org/10.1016/j.jclepro.2020.120843

Raharjo K. 2019. The role of green management in creating sustainability performance on the small and medium enterprises. Management of Environmental Quality:An International Journal 30(3):557-577. https://doi.org/10.1108/MEQ03-2018-0053

Sardianou E, Kostakis I, Mitoula R, Gkaragkani V, Lalioti E, Theodoropoulou E. 2016. Understanding the entrepreneurs' behavioural intentions towards sustainable tourism:a case study from Greece. Environment, Development and Sustainability 18(3):857-879. https://doi. org/10.1007/s10668-015-9681-7

Setiawati CI, Kartini TR. 2018. Understanding the driver motivation of women entrepreneurs in Bandung. Indonesian Journal of Business and Entrepreneurship 4(3):299-307. https://doi. org/10.17358/ijbe.4.3.299

Soomro BA, Ghumro IA, Shah N. 2020. Green entrepreneurship inclination among the younger generation:An avenue towards a green economy. Sustainable Development 28(4):585-594. https:// doi.org/10.1002/sd.2010

Spence M, Ben Boubaker Gherib, J, Biwolé VO. 2011. Sustainable entrepreneurship:is entrepreneurial will enough? ANorth-South comparison. Journal 
of Business Ethics 99(3):335-367. https://doi. org/10.1007/s10551-010-0656-1

Tambunan T. 2019. Recent evidence of the development of micro, small and medium enterprises in Indonesia. Journal of Global Entrepreneurship Research 9(1). https://doi.org/10.1186/s40497018-0140-4

Taylor DW, Walley EE. 2004. The green entrepreneur:opportunist, maverick or visionary? International Journal of Entrepreneurship and Small Business 1(1-2):56-69. https://doi. org/10.1504/IJESB.2004.005377

The Asia Foundation. 2013. Access to Trade and Growth of Women's SMEs in APEC Developing Economies:Evaluating the business environment in Indonesia. The Asia Foundation 53(9):1689-
1699.

UN. 2012. The Future We Want, United Nations Conference on Sustainable DevelopmentRio+20 June 2012, Rio de Janeiro, Brazil. UN Doc A/Conf.216/L.1 , June 2012, 1-53.

United Nations. 2015. TRANSFORMING OUR WORLD:THE 2030 AGENDA FOR SUSTAINABLE DEVELOPMENT. 12-14. https://doi.org/10.1201/b20466-7

Yi G. 2020. From green entrepreneurial intentions to green entrepreneurial behaviors:the role of university entrepreneurial support and external institutional support. International Entrepreneurship and Management Journal 2. https://doi.org/10.1007/s11365-020-00649-y 